\title{
IMPORTANCE OF THE ACTIVITY OF THE COMMUNITY OF RESIDENTS OF RURAL COMMUNES IN OBTAINING EUROPEAN UNION RESOURCES FOR INFRASTRUCTURE INVESTMENTS - BASED ON THE EXAMPLE OF SELECTED RURAL COMMUNES
}

DOI: http://dx.doi.org/10.18509/GBP.2016.48

UDC: 352-027.1(4)

\author{
Ph. D. Małgorzata Dudzińska \\ M.Sc. Jacek Kil \\ Ph. D. Cezary Kowalczyk \\ University of Warmia and Mazury in Olsztyn, Poland
}

\begin{abstract}
:
Poland as a member state of the EU has a possibility of obtaining assistance funds supporting socio-economic development. It is currently the most important instrument of the regional and local development policy. The possibility of obtaining resources from the EU frequently determines the choice of types of investment implemented by SGU.

Self-governments have so far shown great mobilisation in obtaining EU funds. $78 \%$ of communes in Poland obtained support from EU funds for implemented projects. The amount of support obtained by JST in comparison to other groups of recipients makes them the largest recipient of EU assistance.

The activity and efficiency of communes is varied, and so is the scale of obtained financial resources for the implementation of investment projects co-financed from the EU.

Reasons for differences in reaching for European resources are associated with among others varied activity and determination of the authorities of communes for obtaining EU resources.

The social activity of residents is also important. They choose their representatives in the authorities of the commune. Their attitude has an effect on the activity of SGU.

The article attempts to analyse correlations between the social activity of communities in the analysed communes and the amount of obtained support from the EU funds for the implementation of infrastructural investments.

The analysis was performed for three study objects: communes located in three provinces: Warmińsko-Mazurskie, Podlaskie, and Zachodniopomorskie.

The research was conducted with the application of qualitative methods, in particular the analysis and logical construction, including the identification.
\end{abstract}

Keywords: European Union, structural Funds, rural commune, social activity

\section{INTRODUCTION:}

Poland's accession to the European Union permitted self-government units obtaining resources supporting the socio-economic development and increasing their 
competitiveness [8]. Assistance funds constitute a chance for self-government units for the implementation of both infrastructural undertakings and projects related to the development of local communities [11]. Owing to EU funds, self-government units are able to implement investments considerably exceeding their financial possibilities limited by the level of obtained income. This particularly concerns rural communes. The possibility of obtaining resources from the EU determines the type of investment implemented by communes [2]. In spite of many critical opinions regarding the importance of aid measures of the EU and their amount (with consideration of the amount of the member contribution paid by Poland), in the current financial situation of the country it is the most important instrument of the regional and local development policy. Cohesion policy funds constitute a specific type of instrument of resources concentration contributing to the implementation of investments increasing the development potential [10].

So far, self-governments showed very high mobilisation in obtaining EU funds. Each of the provinces, $98 \%$ of districts, and $78 \%$ of all communes in Poland obtained support from EU funds for implemented projects [6].

The amount of the support obtained by Self-Government Units (SGU) in comparison to other groups of recipients makes them the largest recipient of EU assistance. Communes, however, show varied activity and efficiency, and therefore scale of obtained financial resources for the implementation of investment projects co-financed from EU [1]. Many researchers investigate the causes of such a situation. According to Kutkowska [5], the reasons for reaching for EU resources are associated with financial restrictions related to the necessary own contribution and varied experience of commune officials in obtaining EU support. It is possible that also commune authorities attempted to obtain EU resources with varied activity and determination.

The authors of the study believe that the social activity of residents is also of importance. They choose their representatives in the commune's authorities, and influence the functioning of SGU with their attitude.

\section{OBJECTIVES AND METHODS}

The article analysed correlations between the social activity of communities in the analysed communes and the amount of obtained support from EU resources for the implementation of infrastructure investments.

The analysis was performed for three study objects: communes located in three provinces: Warmińsko-Mazurskie, Podlaskie, and Zachodniopomorskie, located in three NUTS 1 regions of Poland (northern, eastern, and north-western, respectively) (Fig. 1).

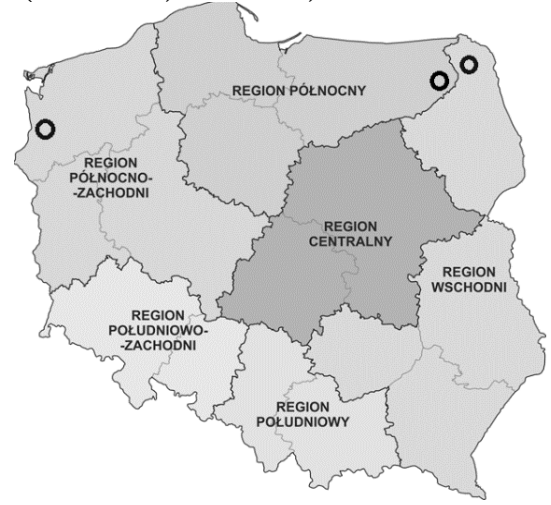


Figure 1. Division of Poland into 6 regions (NUTS 1) with marked study objects Source: $w w w . f u n d u s z e e u r o p e j s k i e . g o v . p l$

Additionally to the determination of correlations between the obtained support and social activity, a synthetic measure of social activity was applied for the communes.

Values of particular features of social activity were ascribed point assessments at a 3degree scale (simultaneously changing destimulants to stimulants). Then, a synthetic assessment of the social activity measure was performed for the commune. The above order was determined based on the qualitative assessment of a given feature (from small potential, through medium, to high potential). The classification was performed due to the type of the available indices, as well as the quality of data available for the analysis. The indices were normalised according to the following algorithm:

1) development of an ordered number sequence for the value of each analysed feature, where: $\mathrm{x} 1=\min .<\mathrm{x} 2<\mathrm{x} 3<\ldots<\mathrm{xn}=\max$.

2) determination of the length of class intervals according to the analysis of the literature on the subject and statistical data, e.g. statistics from the Local Data Bank, from ARIMR.

3) construction of class intervals $\rightarrow$ threshold values for intervals are calculated from subsequent elements of the arithmetic sequence in which the first element (al) corresponds to the lowest value of the numerical series $(x 1=\min$.), and subsequent elements of the sequence are higher than the preceding ones by intervals determined based on the literature and experts. The last element is the highest value of the series $(x n=\max )$;

4) point bonitation of objects $\rightarrow$ elements of the numerical series $x j$ are included to respective classes (intervals) determined by sequence $a i$ based on their value. Therefore, each element $x j$ belonging to interval $<(a i, a i+1)$ adopts a point value equal to $i$, i.e. range value ascribed to the class.

The point assessment employed a 3-degree class interval for each feature (partial index), where the most beneficial value of a feature obtained 3 points, and the least beneficial 1 point. Based on the mean value of points obtained for four features of the assessment and adopted weights, communes with varied social activity were distinguished. The assessment of social activity for the analysed communes was performed according to the scale (Tab. 1).

Table 1. Value of the synthetic measure of social activity in points.

\begin{tabular}{|l|l|l|l|}
\hline $\begin{array}{l}\text { Value of the synthetic measure of } \\
\text { social activity in points }\end{array}$ & Medium & Big \\
\hline Point worth of indicator & $1-1,6$ & $1,7-2,3$ & $2,4-3,0$ \\
\hline
\end{tabular}

The research was divided into the following stages:

At stage I of the research, the quantitative analysis was presented of the analysed investment projects co-financed from the EU resources, implemented in the area of the analysed communes. At stage II, the synthetic measure of social activity was determined for the analysed communes, and correlations were identified between the synthetic measure of social activity and amount of support obtained from the EU for the implementation of infrastructure investments.

The final stage of the research involves drawing conclusions based on the performed research. 


\section{STUDY AREA}

The study objects are rural communes Raczki (Podlaskie province), Prostki (Warmińsko-Mazurskie province), and Banie (Zachodniopomorskie province).

The communes are located in rural areas where the majority of residents support themselves from agriculture, and in communes Prostki and Banie additionally from forestry. Communes Raczki and Prostki are located in the north-eastern part of Poland, and commune Banie in its north-western part (Tab. 2).

Table 2. The comparis on of the analysed communes

\begin{tabular}{|c|c|c|c|c|}
\hline Lp. & The attribute name & $\begin{array}{l}\text { Municipality } \\
\text { Raczki }\end{array}$ & $\begin{array}{l}\text { Municipality } \\
\text { Prostki }\end{array}$ & $\begin{array}{l}\text { Municipality } \\
\text { Banie }\end{array}$ \\
\hline 1 & Voivodship & $\begin{array}{l}\text { Podlaskie } \\
\text { province }\end{array}$ & $\begin{array}{l}\text { Warmińsko- } \\
\text { Mazurskie } \\
\text { province }\end{array}$ & $\begin{array}{l}\text { Zachodniopomo } \\
\text { rskie province }\end{array}$ \\
\hline 2 & Province & suwalski & ełcki & gryfiński \\
\hline 3 & Type of municipality & wiejska & wiejska & wiejska \\
\hline 4 & Surface & $142,25 \mathrm{~km}^{2}$ & $230,47 \mathrm{~km}^{2}$ & $205,81 \mathrm{~km}^{2}$ \\
\hline 5 & $\begin{array}{l}\text { The number of municipal subdivision / } \\
\text { number of villages }\end{array}$ & $34 / 36$ & $40 / 44$ & $15 / 19$ \\
\hline 6 & The number of people & 6027 & 7505 & 6442 \\
\hline 7 & Density of population (people $/ \mathrm{km}^{2}$ ) & 42 & 32 & 31 \\
\hline 8 & Farmland in $\%$ & 73 & 66 & 60 \\
\hline 9 & The number of registered unemployed $\%$ & 3,6 & 13,9 & 9,3 \\
\hline 10 & $\begin{array}{l}\text { The number of Working on the } 1000 \\
\text { population }\end{array}$ & 75 & 87 & 51 \\
\hline 11 & The working age population & 3767 & 4820 & 4184 \\
\hline 12 & $\begin{array}{l}\text { Expenditure municipalities per capita } \\
\text { (PLN) }\end{array}$ & 3236 & 3656 & 3430 \\
\hline 13 & $\begin{array}{l}\text { Total revenue of the municipality } \\
\text { (thousand PLN) }\end{array}$ & 18616 & 28217 & 20929 \\
\hline 14 & $\begin{array}{l}\text { Own income of the commune and } \\
\text { income per resident (thousand PLN) }\end{array}$ & 5467 & 8946 & 8252 \\
\hline 15 & Subsidies per capita (thousand PLN) & 8806 & 10833 & 6997 \\
\hline 16 & $\begin{array}{l}\text { Resources from the national budget or } \\
\text { other granted as co-financing of } \\
\text { programmes and projects implemented } \\
\text { with the participation of resources from } \\
\text { structural finds and the EU Cohesion } \\
\text { find (thousand PLN) }\end{array}$ & 655 & 1628 & 374 \\
\hline
\end{tabular}

STAGE I. QUANTITATIVE ANALYSIS OF IMPLEMENTED INVESTMENT PROJECTS CO-FINANCED FROM EU RESOURCES, IMPLEMENTED IN THE AREA OF THE ANALYSED COMMUNES.

The analysis was based on two periods of absorption of EU resources, i.e. years: 20042006 - the first financial period of Poland's membership in the EU, and 2007-2013 the second financial period (Tab. 3). 
In commune Raczki in the analysed period, 12 projects co-financed with EU resources were implemented. Three projects were implemented in the first, and nine in the second programming period (Tab. 3). In the years 2004-2006, the analysed commune obtained co-financing of projects with a total value of 1228 thousand, and the subsidy amounted to 768 thousand, constituting $62 \%$ of the costs of the implemented investments. In the second programming period in commune Raczki, co-financed projects were implemented with a value of 14617 thousand. The subsidy constituted $75 \%$ of the amount.

In commune Prostki, the lowest number of projects co-financed from the EU was implemented among all of the analysed communes. In the first programming period, no project was implemented. In the years 2007-2013 - eight projects (Tab. 3). The commune obtained a subsidy for the implementation of projects to the amount of 8790 thousand. The value was equivalent to $62 \%$ of the costs of the implemented projects.

In the third of the analysed communes - commune Banie, quite a high number of projects (12) were implemented with the contribution of EU resources in the period 2004-2013. In the first programming period, only one project was implemented, but in the second period, already 11, and the total amount of the subsidy equalled 4355 thousand PLN (Tab. 3).

The highest subsidy amount for the implementation of the analysed projects was obtained by commune Raczki, and the lowest by commune Banie. Calculating the amount per resident and the area of the commune, for the self-government unit from the Podlaskie province it amounts to, respectively: 1957 PLN/person and $83000 \mathrm{PLN} / \mathrm{km}^{2}$ from Warmińsko-Mazurskie - $1171 \quad$ PLN/person, $38000 \quad$ PLN/km², Zachodniopomorskie - $676 \mathrm{PLN} /$ person and $21000 \mathrm{PLN} / \mathrm{km}^{2}$. The amounts of the obtained subsidy in commune Raczki are almost three times higher than in commune Banie per resident, and almost four times higher in relation to the area of the commune.

Commune Raczki has the smallest area among the analysed communes, and obtained the lowest total income per resident and own income in 2014. Nonetheless, it obtained the highest subsidies from EU resources in the analysed period.

Table 3. List of infrastructural ventures co-financed from European funds by Raczki, Prostki and Banie Districts between 2004 and 2013.

\begin{tabular}{|c|c|c|c|c|c|}
\hline 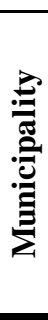 & 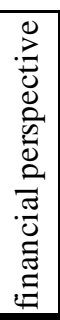 & $\underset{\Xi}{\stackrel{\Xi}{\Xi}}$ & 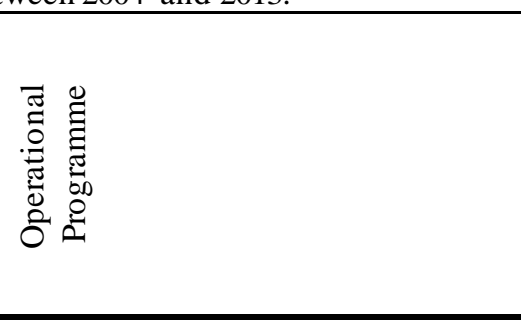 & 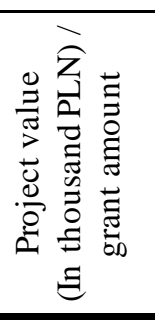 & 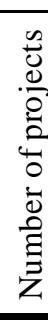 \\
\hline \multirow[b]{2}{*}{ 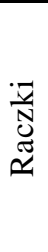 } & \multirow{2}{*}{ 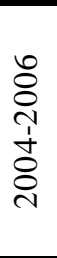 } & $\begin{array}{l}\text { European Regional Development } \\
\text { Fund }\end{array}$ & $\begin{array}{l}\text { Integrated Regional Operational } \\
\text { Programme "Rural areas" }\end{array}$ & $596 / 342$ & 1 \\
\hline & & $\begin{array}{l}\text { European Agricultural Guarantee } \\
\text { Fund }\end{array}$ & $\begin{array}{l}\text { Sectoral Operational Programme } \\
\text { Restructuring and Modernisation of } \\
\text { the Food Sector and Rural } \\
\text { Development } 2004-2006\end{array}$ & $632 / 426$ & 2 \\
\hline \multirow{3}{*}{ 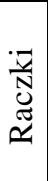 } & \multirow{3}{*}{$\begin{array}{l}\frac{m}{0} \\
\stackrel{1}{1} \\
\frac{1}{8} \\
\stackrel{1}{1}\end{array}$} & $\begin{array}{l}\text { European Agricultural Fund for } \\
\text { Rural Development }\end{array}$ & Rural Development Programme & $3310 / 1777$ & 2 \\
\hline & & European Social Fund & Innovative Economy Programme & $477 / 406$ & 1 \\
\hline & & European Regional Development & Operational Programme for the & $279 / 234$ & 1 \\
\hline
\end{tabular}




\begin{tabular}{|c|c|c|c|c|c|}
\hline & & Fund & Podlaskie Voivodeship & & \\
\hline & & $\begin{array}{l}\text { Regionalnego } \\
\text { European Regional Development } \\
\text { Fund }\end{array}$ & $\begin{array}{l}\text { The Operational Programme } \\
\text { Infrastructure and Environment }\end{array}$ & $9301 / 7899$ & 3 \\
\hline & & European Fisheries Fund & The draft OP FISH & $1250 / 709$ & 2 \\
\hline \multirow{3}{*}{$\begin{array}{l}\vec{y} \\
\stackrel{5}{0} \\
0 \\
0\end{array}$} & \multirow{3}{*}{ 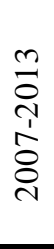 } & $\begin{array}{l}\text { European Agricultural Fund for } \\
\text { Rural Development }\end{array}$ & Rural Development Programme & $2126 / 979$ & 4 \\
\hline & & $\begin{array}{l}\text { European Regional Development } \\
\text { Fund }\end{array}$ & $\begin{array}{l}\text { Operational Programme for the } \\
\text { Warmia and Mazury }\end{array}$ & $\begin{array}{l}11341 / 719 \\
7\end{array}$ & 3 \\
\hline & & $\begin{array}{l}\text { European Regional Development } \\
\text { Fund }\end{array}$ & Innovative Economy Programme. & $614 / 614$ & 1 \\
\hline 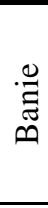 & 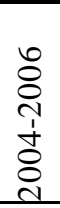 & $\begin{array}{l}\text { European Regional Development } \\
\text { Fund }\end{array}$ & $\begin{array}{l}\text { Community Initiative Programme } \\
\text { INTERREG } \\
\text { III A } \\
\text { Polska-Meklemburgia }\end{array}$ & $109 / 82$ & 1 \\
\hline \multirow{3}{*}{ 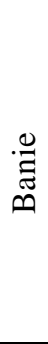 } & \multirow{3}{*}{ 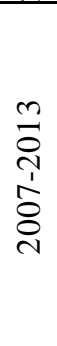 } & $\begin{array}{l}\text { European Agricultural Fund for } \\
\text { Rural Development }\end{array}$ & Rural Development Programme & $4307 / 1841$ & 8 \\
\hline & & $\begin{array}{l}\text { European Regional Development } \\
\text { Fund }\end{array}$ & $\begin{array}{l}\text { Operational Programme for the } \\
\text { West Pomeranian Voivodeship }\end{array}$ & $1212 / 850$ & 2 \\
\hline & & $\begin{array}{l}\text { European Regional Development } \\
\text { Fund }\end{array}$ & $\begin{array}{l}\text { Inicjatywa Wspólnotowa } \\
\text { INTERREG IVA } \\
\text { Community Initiative Programme } \\
\text { INTERREG }\end{array}$ & $1890 / 1582$ & 1 \\
\hline
\end{tabular}

Source: Own compilation by Dudzińska (2015).

\section{STAGE II DETERMINATION OF THE SYNTHETIC MEASURE OF SOCIAL ACTIVITY.}

The map of rural areas developing in Poland will change depending on human activity permitting more efficient and dynamic development of the space [3]. Researchers of social capital assume that the source of economic success involves in $80 \%$ free market, and in $20 \%$ social capital [4].

The social activity of residents of rural areas is defined as the entire spectrum of various activities and behaviours aimed at solving problems of the local community.

Social activity has a certain individual aspect, not boiling down to the influence of common factors, because it results from people's determination to act and will of selforganisation, and depends on individual and collective choices and decisions [7].

Social activity involves individual as well as collective activities, single and regular, spontaneous and planned actions. Moreover, empirical research on social activity always involves searching for factors and elements of the social structure contributing and hindering undertaking activity [9].

Considering the complexity of social activity, it is difficult to find measures for describing the ability of residents to cooperate in the social interest through the measurement of civic activity (citizenship), social activity defined in the context of civic society (active citizens and informal and formal institutions developed by them), and their activity in undertaking socio-economic initiatives for the development of the local environment (e.g. activity in the application for external financial support).

The choice of variable indices in quantitative analyses is usually a resultant of the availability of data and arbitrary decisions of researchers. The basis for the adopted choice, however, should be strong substantive justification. The research adopted voter 
turnouts published by PKW in presidential elections 2015 as the average from the first and second round of the elections, voter turnout in self-governmental elections 2014 for the council of communes - voting statistics, number of foundations and associations (except OSP) per 10 thousand residents by province in rural areas in 2014, and number of beneficiaries of the Rural Development Programme 2007-2013 axis 4 LEADER (measure 413 - implementation of local development strategies, 421 - implementation of cooperation projects, and 431 - functioning of the local action group, acquisition of skills, and activation) per 10 thousand residents of the district, describing socioeconomic initiatives for the development of the local environment. Tab. 4 presents values of the aforementioned features of social activity in the analysed communes.

Table 4. Features describing social activity in the analysed communes.

\begin{tabular}{|c|c|c|c|c|}
\hline Lp. & Name features & $\begin{array}{l}\text { Municipali } \\
\text { ty Raczki }\end{array}$ & $\begin{array}{l}\text { Municipa } \\
\text { lity } \\
\text { Prostki }\end{array}$ & $\begin{array}{l}\text { Municipa } \\
\text { lity } \\
\text { Banie }\end{array}$ \\
\hline & $\begin{array}{l}\text { Distribution of turnout in presidential elections } 2015 \\
\text { According to the acquired point scale }\end{array}$ & $\begin{array}{l}47,70 \% \\
3\end{array}$ & $\begin{array}{l}32,01 \% \\
1\end{array}$ & $\begin{array}{l}36,56 \% \\
1\end{array}$ \\
\hline & $\begin{array}{l}\text { Distribution of turnout in self-government elections } 2014 \\
\text { According to the acquired point scale }\end{array}$ & $\begin{array}{l}49,53 \\
2\end{array}$ & $\begin{array}{l}51,05 \\
3\end{array}$ & $\begin{array}{l}43,28 \\
1\end{array}$ \\
\hline & $\begin{array}{l}\text { Number of foundations and as sociations (except OSP) per } \\
10 \text { thous and residents } \\
\text { According to the acquired point scale }\end{array}$ & 1 & 2 & 3 \\
\hline & $\begin{array}{l}\text { Number of beneficiaries of the Rural Development } \\
\text { Programme } 2007-2013 \text { axis } 4 \text { LEADER per } 10 \text { thousand } \\
\text { residents of the district. } \\
\text { According to the acquired point scale }\end{array}$ & 3 & 1 & 1 \\
\hline & $\begin{array}{l}\text { The total amount of obtained EU resources in the years } \\
2004-2013 \text { for infrastructure investments (PLN). }\end{array}$ & $\begin{array}{l}11792 \\
\text { thous and }\end{array}$ & $\begin{array}{l}8787 \\
\text { thous and }\end{array}$ & $\begin{array}{l}4355 \\
\text { thousand }\end{array}$ \\
\hline & Value of the synthetic measure of social activity in points & 2,2 & 1,7 & 1,6 \\
\hline
\end{tabular}

The synthetic measure of social activity was calculated with consideration of four indices described above.

The methodology was adopted for the synthetic measure of social activity. The following considered features: number of foundations and associations (except OSP) per 10 thousand residents of the commune, and number of beneficiaries of the Rural Development Programme 2007-2013 axis 4 LEADER per 10 thousand residents of the district, explain the measure of social activity the most accurately. They were ascribed a weight of 30 points each. Features related to frequency (self-government and presidential elections) -20 points each.

In the synthetic approach, the index of social activity was the most beneficial in the case of commune Raczki, and amounted to 2.2, corresponding to medium potential. In this commune, the highest EU support was obtained for the implementation of infrastructure investments. The lowest level of the synthetic index of social activity was determined for commune Banie - only 1.6, corresponding to small potential (the lowest amount of 
support was obtained in this area). Commune Prostki obtained an assessment of the synthetic measure of 1.7 points, corresponding to medium potential.

\section{CONCLUSIONS:}

1) In the studied communes, the activity and efficiency, and therefore scale of the obtained financial resources for the implementation of investment projects cofinanced from the EU was varied. The smallest commune with the lowest income per person obtained the highest amount of support, and implemented 12 projects (1957 PLN/resident, $83000 \mathrm{PLN} / \mathrm{km}^{2}$ of the area of the commune).

2) A correlation occurs between the level of obtaining support from the EU for infrastructure investments and social activity of the residents of the commune. The synthetic index of social activity was varied to the degree similar to the amount of the obtained support for infrastructure investments.

3) Through the selection of their representatives and their attitude, residents indirectly influence activities implemented by SGU, and shape their surroundings. By introducing tools increasing social activity of residents in a given area, we can influence the implementation of self-government policy, and therefore the amount of obtained support for the implementation of infrastructure investments in the commune.

\section{REFERENCES}

[1] Dudzińska. M.. Rozpoznanie skuteczności pozyskania i efektywnego wykorzystania unijnego wsparcia na przedsięwzięcia infrastrukturalne w gminach - studium przypadków, Acta Sci. Pol., Administratio Locorum, Poland, vol. 16 (4), 2015.

[2] Grzebyk, M.. Działalność inwestycyjna miasta Rzeszów w latach 2004-2006. Problemy ekonomii, polityki ekonomicznej i finansów publicznych, [red.] Sokołowski, J., Prace Naukowe Uniwersytetu Ekonomicznego we Wrocławiu, Poland, vol. 39, pp 59-67, 2009.

[3] Kołodziejczyk, D.. Kapitał społeczny w rozwoju obszarów wiejskich, Współczesne przeobrażenia i przyszłość polskiej wsi, Studia Obszarów Wiejskich, Poland, vol. 4, pp 27-37, 2003 .

[4] Kołodziejczyk, D.. Wasilewski, A., Identyfikacja instytucji działających na obszarach wiejskich 8, IERiGZ, Poland, 2005.

[5] Kutkowska, B., Struś, M.. Wykorzystanie funduszy strukturalnych UE do realizacji celów rozwojowych na przykładzie wybranych gmin Dolnego Śląska, Wieś i Rolnictwo, vol. 3, pp 156-181, 2011.

[6] MRR - Ministerstwo Rozwoju Regionalnego, Departament Koordynacji Programów Regionalnych, Przegląd Regionalny vol. 2. Doświadczenia i szanse regionów, Poland, 2008.

[7] Rosner, A., Stanny, M.. Monitoring rozwoju obszarów wiejskich. Etap I. Fundacja Europejski Fundusz Rozwoju Wsi Polskiej, Instytut Rozwoju Wsi i Rolnictwa PAN, 2014.

[8] Standar, A., Puślecki, Z. W.. Ocena zastosowania środków polityki regionalnej Unii Europejskiej przez samorządy gminne województwa wielkopolskiego, Poland, 2011. 
[9] Surowiec, K., Badania socjologiczne nad aktywnością społeczną mieszkańców polskiej wsi, Studia Sociologica, Poland, vol. 20, pp 67-87, 2010.

[10] Wyszkowska, D.. Pozyskiwanie środków pomocowych Unii Europejskiej przez gminy województwa podlaskiego, Gospodarka Narodowa, Poland, vol. 10, pp 97-112, 2010.

[11] Zawora, J.. Wykorzystanie funduszy Unii Europejskiej do finansowania zadań jednostek samorządu terytorialnego, Wpływ funduszy unijnych na działalność gospodarczą. Nierówności społeczne a wzrost gospodarczy, Poland, vol. 27, pp 136147, 2012. 